\title{
Characteristics of Human Interactions between Daystar University National and International Students: an Intercultural Communication Perspective
}

\author{
Article by Henri Buregea Bin Rwakenda \\ Ph.D. in Education, Texila American University, Congo \\ E-mail: henry.buregea@texilaconnect.com
}

\begin{abstract}
The purpose of the study was to determine the characteristics and other factors that Daystar University National and International Students exhibit during their interactions and which are likely to affect the quality of their interactions. Further, it sought to classify these characteristics according to the levels of intercultural communication, describe the process they use to restore relationships when misunderstanding occurs, and to suggest an intercultural communication model that would help both national and international students to communicate effectively. Qualitative research approach was used as method of data collection: Focus Group Discussions and In-Depth Interview sessions were organized. The study found that intercultural interactions in Daystar University Students were not as healthy as they should be because some were characterized by factors that are not conducive to fruitful interactions. On the one hand, among other characteristics, national students tend to be individualistic, not caring, assertive, and aggressive. On the other hand, International Students tend to cluster in groups according to their countries of origins and or regions and have a tendency to withdraw whenever misunderstanding occurs. Age, gender, money and environment were the other factors that impact negatively the quality of interactions between the two categories of students. In relation to these findings, the researcher posited that improvement of human interactions between National and International Students and other members of the University is possible if: 1) Students could be helped to meet regularly and share their communication experiences, 2) The current orientation training program could be completely revisited in both content and procedures of execution, 3) An intercultural communication forum could be organized each semester for everybody in the University so that difficulties encountered could be shared and discussed in a way that leads to mutual understanding not only between students but also between students and other members of Daystar University as a community, and 4) Intercultural communication video programmes, seminars and conferences based on intercultural communication case studies could be organized in the University.
\end{abstract}

\section{Problem setting}

\section{Introduction and background}

The study of everyday interaction as it occurs between people in their face to face relationship is very vital for the existence of any group of peoples, society, and organizations. Miell and Dallos $(1996,25)$ wrote; "form and detail can make important differences to the course of relationships. How something is said and done, as well as what is said and done, affect people's expectations and understanding of each other." It is obvious that how something is said and what is said and done affects our interactions, which is true of Daystar University given its multi-national population composition. Besides being an education institution, it is also a Christian University. For this reason, people have to interact and for their interaction to be positive, effective communication is a must. Positive interaction should be a blending of interpersonal and intercultural communication skills, both aimed at conditioning the smooth running of any institution. It is evident that whenever you have 
people from different cultural backgrounds, interaction becomes difficult to handle because of differences in individuals, cultures, knowledge, beliefs, and so forth.

As noted by Adler (1995), increased exposure and the rising diversity of American culture for instance, make an understanding of intercultural communication essential. In order to appreciate this phenomenon, it is paramount to understand the meaning and differences of various concepts: culture, co-culture, ethnicity, race, and intercultural communication. Furthermore, attitude, knowledge and skills (Ibid) are important and crucial concepts of intercultural communication. In addition, motivation to communicate is an important ingredient in successful interaction, regardless of the cultures involved (Ibid).

Examining organizational behavior, Schermerhorn, Hunt \& Osborn (1996) examined some key individual difference factors between employees and how they can be matched with an organization's current and future job requirements. Differences ranging from demographic (gender, age, ethnicity), competency (aptitude, abilities), and personality (individual traits) play a significant role in the quality of interactions and also crucial for the organization to fulfill its overall mission and philosophy. Therefore, the quality of interaction at Daystar University's campuses affects, ipso facto, the quality of its graduates. Hence, the need for a critical analysis of human interactions between Daystar University National and International students.

The continuity of society, specifically Daystar University, depends on its recurring revitalization (Lemon, 972, 1).

\section{Problem statement}

Without interaction, selfhood could not emerge since each person's self is the product-inprocess of human interaction (Gudykunst, 1983, 90). Interactions and relationships are therefore central to most people's everyday lives (Miell and Dallos, 1996, 2). Miell and Dallos further indicated that people who excessively isolate themselves and are lonely may be more prone to negative feelings and may also deteriorate physically and emotionally (Ibid.). Daystar University students are prone to this because of their diverse cultural values, beliefs, and patterns of behavior, which affect the way we interact with others. Whereas the university teaches communication skills, in an interview (Dec 2000), the University International Student advisor pointed out interactions have not been healthy and the Hostel Wardens also added that several cases of misunderstandings had been reported. This was due to different factors, such as nationality, pride, age, political. Though Banks (1995) stated that a timeless adage reminds us that no two people are exactly alike, the dissimilarities can have immense practical consequences on interactions and could lead to misunderstandings.

\section{Research questions}

The Research questions were:

1. What characteristics do national and international students exhibit during their interactions?

2. Which other factors are associated with their interactions?

3. How do they proceed to restore relationships when misunderstanding occurs?

\section{Purpose of study}

The purpose of the study was to determine the characteristics and other factors that Daystar University national and international students exhibit during their interactions

\section{Objectives of the study}

In an attempt to fulfill that purpose the researcher established the following research objectives:

to determine the characteristics and other related factors that Daystar University National and International students exhibit during their interactions; to classify these characteristics according to the levels of intercultural communication and explain how these characteristics 
and related factors affect interactions between Daystar University National and International Students, to describe the process used by both categories of students to bring about understanding when they encounter communication difficulties to suggest an intercultural communication model that could improve the quality of interactions between Daystar University National and International Students.

\section{Assumptions of the study}

The assumptions of the study were Daystar University National and International Students were interested in issues concerning interaction between students. Thus, they were expected to actively participate in Focus Group Discussions by speaking out about their interactions; the Orientation Programme executed in Daystar University did not stress key elements of intercultural communication to all international students, hence, some of these students encountered intercultural difficulties; Daystar University National and International Students come from different countries, hence they presented cultural dissimilarities that could lead to misunderstanding; students who were chosen to participate in Focus Group Discussions were representatives of their national cultures, having been born and raised in those cultures.

\section{Rationale of the study}

Most researchers in the field of International Communication have been from the West; Miller (1994) for instance, wrote about problems that Daystar University African Consortium Students face in the United States and other researchers have focused on intercultural communication problems that short-term missionaries from outside Kenya, especially those from the West, do face in Kenya. What was needed was a study that could create awareness about intercultural communication difficulties that people experience when they live in cultures different from theirs. As students come from different cultures, it was crucial to note what they value, believe in, and how they behave. These could lead to misunderstandings due to dissimilarities between their values, beliefs, attitudes, knowledge, and so forth. It was important to analyze all these dynamics in a defined social context. Daystar University National and International Students' interactions was the selected context.

\section{Significance of the study}

The findings of the study were expected to be beneficial to Daystar University National and International Students in order to improve on their interaction, which is one of the crucial aspects of communication. The findings would also be important to other institutions of higher learning, similar to Daystar University and also, revision of the existing Orientation Training Programme of Daystar University was expected. The study was a necessary undertaking in order to fulfill the requirement for the award of the Master of Arts Degree in Communication and to acquaint the researcher with practical insights gained from the use of qualitative research methods.

\section{Limitations and delimitations of the study}

The study was confined to interactions between Daystar University National and International Students and also required that only students who have been studying for at least one year be selected for the sample. The study focused on descriptions of most common interpersonal and intercultural communication problems. Many of the students came from countries engaged in war; this could have made these students reluctant to participate in Focus Group Discussions. The researcher explained in advance to the students important details as to why the discussions were held. The researcher guaranteed participants that all the discussions were for research purposes only and that the findings would not have negative implications on their being at Daystar University.

\section{Methodological approach}

The study was qualitative in nature and used Focus Group Discussions and In-depth Interviews as methods of data collection. Questionnaires were pre-tested before conducting 
Texila International Journal of Academic Research

Volume 3, Issue 2, Dec 2016

eight (08) Focus Group Discussions and fourteen (14) In-depth Interviews in two Daystar University Campuses (Athi River Campus and Valley Road Campus). These were both taperecorded and a qualified and reliable research assistant transcribed the recorded outcomes, then the researcher processed, analyzed, and interpreted the data.

\section{Literature review}

\section{Introduction}

The purpose of the study was to determine the characteristics that Daystar University National and International Students exhibit during their interpersonal interactions and to describe these characteristics according to pertinent intercultural communication concepts. The other reason was to describe the process students used in order to restore relationships when misunderstanding occurred, and to suggest an intercultural communication model that could help both national and international students communicate effectively. These chapter highlighted the concepts and laid out the theoretical foundation for this particular study. The chapter was made up of the following areas: communication, communication and culture, intercultural communication, interpersonal communication, attribution theory, facenegotiation theory, interpersonal and intercultural communication, barriers to effective intercultural communication, education for the intercultural experience, towards an intercultural communication competence, and the theoretical framework for effective intercultural communication.

\section{Communication}

The study of human interactions being central to the study of communication, recent studies (Civikly, 1981; Samovar \& Porter, 1997) showed that communication is interactive. Trenholm and Arthur (1996) argued that there was still disagreement on how to define communication, although the subject had been written about for over 25 centuries. For this study, communication was understood as a process whereby humans collectively create and regulate social reality" (Ibid.). Myers (1974) indicated communication as a process that includes a series of interlinked events commencing under certain defined conditions and concluding under defined conditions. Samovar \& Porter (1997) defined communication as a dynamic transactional behavior-affecting process in which people behave intentionally to induce or elicit a particular response from another person. To these authors, communication is complete only when the intended behavior is perceived by the intended receiver and responds to that behavior.

\section{Communication and culture}

Kohls (1984) indicated that communication takes place in the medium of culture. And therefore, to discuss intercultural communication requires some understanding of the concepts of communication and culture (Sarbaugh, 1979, 1). In the same vein, Mbennah (1994) indicated that the influence of culture on the communication process is so significant that communication is almost defined by culture. Dodd (1991) also confirms that communication is central to culture. While, Lenfers (1997) held that for the social anthropologist, the term culture denotes "the entire range of the recurring patterns of behavior that characterize the life of a community." These patterns vary from culture to culture and thus, communication reflects all these differences. Kluckhohn said, "Culture is a way of thinking, feeling, believing. It is the group's knowledge stored up for future use” (Hesselgrave, 1978, 68). Dodd (1991) maintains that cultures inherently contain communication systems. Whereas, Smith (1966) believed that communication and culture are inseparable. The consequence therefore is that styles of communication vary from culture to culture, and thus interactions across cultures may be difficult. 


\section{Intercultural communication}

Communication has content and relationship (Dodd, 1991, 29). Argyle provided a different overview of communication that "many people have to communicate and work with members of other cultures" (Ibid.). And due to the differences that exist across cultures, Argyle believed that particular communication problems would arise (in Samovar \& Porter, 1988, 4). Meanwhile, Watzalawick, Beavin, and Jackson (1967) emphasized that communication does not exist in content isolation. Scholars such as Hall and Whyte detailed some of the communication problems that are caused by different cultures assigning different meanings to time, space, and social levels and being unaware of such differences (in Devito 1976, 206). Samovar \& Porter (1997) indicated that the link between culture and communication is crucial to the understanding of intercultural communication. This is supported by Edward Hall that culture provides a highly selective screen between people and their outside worlds $(1988,4)$. This however involves two concepts: culture ideal and culture pattern. Culture ideal being a verbalized formulation of normative patterns for behavior as stated by the members of a given society, while the latter is a form of behavior that has become normative by the consensus of the members of a society.

Samovar \& Porter (1997) explain that the communication repertoires people possess can vary significantly from culture to culture, leading to all sorts of difficulties. This evidenced by the description of "Six Fundamental Patterns of Cultural Differences" that can be the sources of misunderstanding (DuPraw \& Axner [on-line], 2000, 2-3). They further argue that the way people communicate varies widely between, and even within cultures. Also, the degree of importance given to non-verbal communication varies across cultures. Different norms associated with the appropriate degree of assertiveness in communicating can add to cultural misunderstandings. In the same way, some cultures view conflict as a positive thing while others view it as something to be avoided. In educational institutions like Daystar University, it is not rare to encounter communication difficulties that often lead to open conflicts between its members. On task accomplishment, there are different ways that people move toward completing tasks from culture to culture.

Moreover, DuPraw \& Axner ([on-line], 200, 3) asserted that the roles individuals play in decision-making vary widely from culture to culture. For instance, in the U.S, decisions are frequently delegated; in Japan, consensus is the preferred mode, and in Southern Europe and Latin America, there is a strong value placed on holding decision-making responsibilities to oneself. Also, it is not appropriate to be frank about emotions in some cultures, yet in others it is viewed negatively. There are also differences that occur among cultural groups in regards to epistemologies. Thus, recognizing where cultural differences arise is the first step towards settling the various communication gaps across cultures. Devito (1992) stated language reflects culture, cultural differences create uncertainty, and initial interactions being crucial as the intercultural communication principles. During initial interactions, uncertainty reduction is expected to enhance individuals' perceived ability to forecast future relational outcomes (Sunnafrank, 1986, 3).

\section{Interpersonal communication}

Interpersonal communication occurs between two persons, called a dyad (Ibid.). In line with this, Patton \& Griffin asserted that we are concerned with the face-to-face interactions between people who are consistently aware of each other, when it comes to interpersonal communication. Wood (1999) expounded on this view that "interpersonal communication is a selective, systematic, unique, and on-going process of interaction between individuals who reflect and build personal knowledge of one another and create shared meanings. "DeVito (1992) illustrated openness, empathy, supportiveness, positiveness, equality, confidence, immediacy, interaction management, expressiveness, and other-orientation as the "Principles of Effective Interpersonal Communication. 
Texila International Journal of Academic Research

Volume 3, Issue 2, Dec 2016

\section{Attribution theory}

Attribution theory suggests that we attempt to understand the behaviors of others, and in the process, make inferences about their motivations (De Vito, 1988). This theory refers to the reason one finds to explain the outcome that has occurred (Patton \& Griffin, 1981, 86). Adler et al. pointed out that attribution is "the process of making sense of another person's behavior" (1995, 396). Meanwhile, Woolfolk (1990) define attribution theories as cognitive explanations of motivation which begin with the assumption that we all ask, "Why?" in our attempts to understand our successes or failures. Attribution also suggests that the explanation people give for behavior, particularly their own successes and failures, have strong influences on future plans and performances. Casmir (1985) stressed the importance of roles, stereotypes, and schemata - the entire perceptual cycle-as part of understanding communication and social cognition.

Dodds (1991) indicated that what is often called social cognition really boils down to a fundamental cognitive process called social categorization, which Gudykunst \& Grumbs (1989) claimed that it leads to positive bias toward the in-group and a negative bias toward the out-group. Therefore, the type of interaction depends on whether the interactions consider themselves to be in-group or an out-group. Even then, Gallois, Franklyn-Stakes, Giles, and Coupland (in Dodd, 1991) discussed "communication accommodation," which refers to how we attune ourselves and adapt to another person, as a major dynamic of social categorization. Among others, Ehnrenhaus (1983) extended attribution to intercultural communication.

\section{Face-negotiation theory}

Stella Ting Toomey's face negotiation theory helps explain cultural differences in response to conflict. Verderber \& Verderber (1992) asserted that "according to Ting Toomey, when the framework is different, the style of handling conflict will vary as well. For instance, a culture in which information about procedure is rarely communicated is called a high-context culture or HCC (Hall, 1977). In a low context culture (LCC), information is abundant, procedures are explicitly explained, and expectations are discussed frequently. Although popular Western wisdom regards face as a sin preoccupation, Ting Toomey and relational researchers find it to be a universal concern. That is because face is an extension of self-concept. In their welldeveloped theory of politeness, Penelope Brown and Stephen Levinson (in Verderber \& Verderber, 1992) defined face as "the public self-image that every member of society wants to claim for him/herself. Taiwanese scholar Yutang called face "a psychological image that can be granted and lost and fought for dignity and presented as a gift."Ting Toomey simply refers to face as "the projected image of one's self in a relational situation." Tim Toomey's 2 x 2 grid (in Verderber \& Verderber, 1992, 424-425) of face work maintenance yields four distinct public self-image: face restoration, face saving, face assertion, and face giving. She believes that individuals from a given society can negotiate face using any or all of these four approaches.

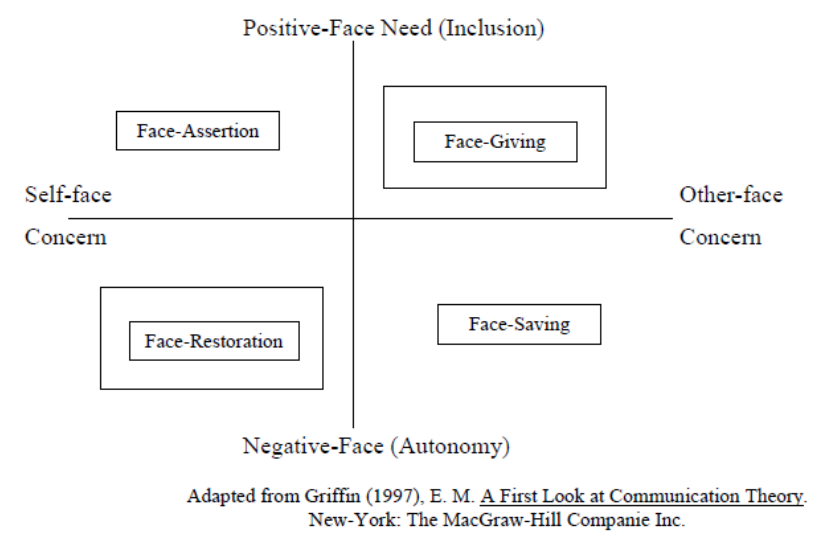

Figure 1. The four types of faces 
Goffman (1967) defined face as:

The positive social value a person effectively claims for himself by the line others assume he has taken during a particular contact. Face is an image that others may share, as when a person makes a good showing for his profession or religion by making a good showing for himself.

Moreover, it is important to indicate that any attribution can lead to either negative or positive outcome. Thus, a brief glance at the relationship between interpersonal and intercultural communication is required.

\section{Interpersonal and intercultural communication}

In trying to establish some degree of personal contact, and getting connected to each other, and even transcend cultural differences, communicators were believed by Fred Casmir (1991) to have created what is called a "third culture." For mutual understanding to happen when communicating, there was a need for the university to create a third culture. In fact, communication means trying to establish a commonness with someone (Smith, 1992, 25). Thus, a third culture could occur if there was a consistent effort to bring about more commonness between students despite dissimilarities existing between them. Adopted from Adler et al. (1995), the following illustration represents the relationship between interpersonal and intercultural communication.

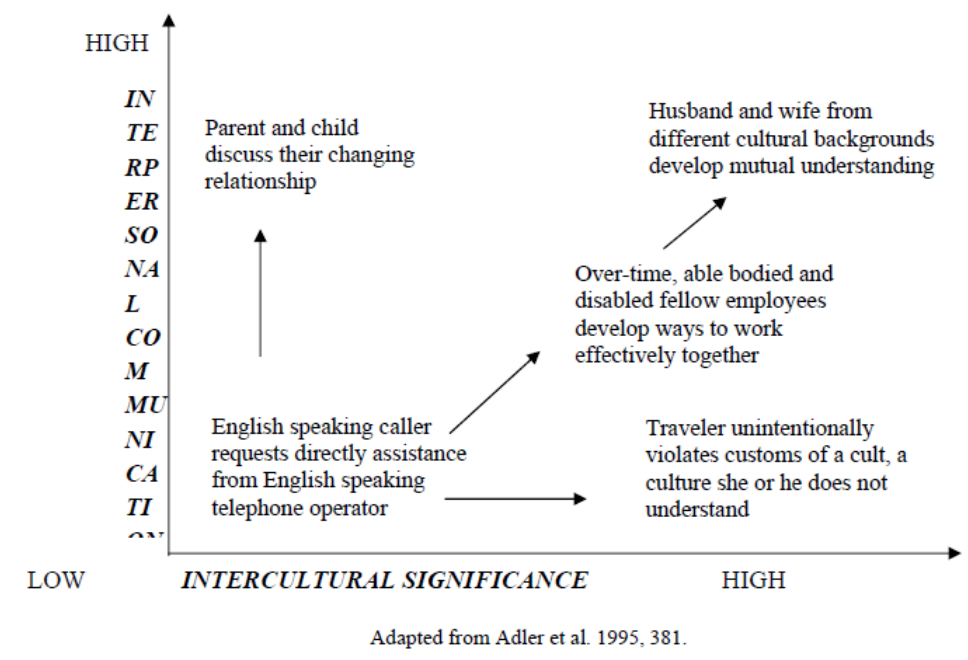

Figure 2. Relationship between Interpersonal and Intercultural Communication

The above model shows that some interpersonal transactions have virtually no intercultural elements. Other countries are almost exclusively intercultural, without personal dimensions of communication. Still other exchanges - the most interesting for the purpose of the studycontain elements of both intercultural and interpersonal communication (Ibid.).

\section{Barriers to effective intercultural communication}

Experience shows that most of the time in intercultural encounter, cultural superiority, fear and anxiety make the genesis of potential intercultural barriers that both participants in intercultural interactions are likely to experience. Tafoya (in Gudykunst, 1983) defined a barrier to interpersonal communication as "anything that prevents, restricts or impedes the conveyance of meaning, by words or gesture between two or more persons in social settings. "Barna (in Samovar \& Porter, 1997) calls these same barriers stumbling blocks in intercultural communication. Barna went ahead and identified six barriers or stumbling blocks: assumptions of similarities, language differences, non-verbal misinterpretations, preconceptions and stereotypes, tendency to evaluate, and high anxiety or tension.

In addition, Infant and Womack (1993) suggested that selective perception also affects communication with someone from a different culture. On language, for instance the use of "Sheng" that Gathu (1995) considers as Swahili nativization, barriers include language 
Texila International Journal of Academic Research

Volume 3, Issue 2, Dec 2016

differences, differences in pronunciation, intonation, and use of local idioms and phrases. Value differences also cause ambiguity in intercultural communication. Several other causes of difficulty in any social interaction may include: ethnocentrism (Ruhly, 1976 in Infante \& Womack, 1993), stereotypes, prejudice, selective response, and what Kohls (1984) pointed out to play tricks on us: perception. In this study, the researcher traced how the issue of perception impacts interactions that take place between national and international students.

\section{Education for the intercultural experience}

Bennett (1993) pronounced that education and intercultural communication is an approach to changing our "natural" behavior. The author asked learners to transcend traditional ethnocentrism and to explore new relationships across boundaries. Ethnorelativism, a developmental model which is ideally based upon key organizing concepts (Op. Cit. 22) posits a continuum of increasing sophistication in dealing with cultural differences. Three basic assumptions explain the worth of this developmental model: the phenomenology of difference is key to intercultural sensitivity, the difference necessary for intercultural sensitivity is that of ethnorelativism, and ethical choices can and must be made for intercultural sensitivity to develop.

The developmental model that Bennett suggested is made up of the following stages: denial, defense, minimization, acceptance, adaptation, and integration. The first three stages constitute ethnocentric stages whereas the last three make the ethnorelative stages. Education for intercultural experience will be efficient if and only if human beings strive to create and maintain responsible world citizenship, which Nussbaum stated that it requires us 'to cultivate our humanity,' which consists of examining our own traditions, seeing ourselves connected to those beyond our localities (in Idoc Internationale, 1999, 41). In the same vein, Nyamnjoh held that "good communication has been presented as a means of being able to break through blockages (backward attitudes and practices_customs, traditions, and philosophies) with knowledge" (in Okigbo, 1995, 435). Attempting to acquire this good communication is a basic step in the process of becoming competent in intercultural communication endeavors.

\section{Towards an intercultural communication competence}

Although conversations defer depending on the topic, context, and relationship of interactants, it is important that certain factors consistently facilitate rewarding or nonrewarding conversations (Coker \& Burgoon, 1987, 463). This involvement in this conversation should be viewed from a functional perspective and conceptualized as entailing five dimensions: immediacy, expressiveness, interaction management, altercentrism, and social anxiety (Ibid.). These dimensions were used by the researcher to indicate and classify elements of communication that are affected in intercultural encounter in Daystar University and which become barriers to effective communication. According to Ruhly (1976), there are two important skills or attitudes that are especially important in intercultural communication: empathy and ability to step outside one's own culture to consider different explanations for a puzzling event (in Infante et al., 1993, 435). Empathy is a personality trait that presumably enables newly mobile individuals to operate efficiently in a changing social environment (Segall et al., 1990). People become better intercultural communicators when they are more flexible in inferring motives or attributing meaning to another's behavior.

\section{Theoretical framework for effective intercultural communication}

Wilbur Schramn indicated that communication comes from the Latin communis, commonness (in Devito, 1976, 11). He posited that when we communicate, we are trying to establish a commonness with someone. Communication always requires at least three elements - the source, the message, and the destination (Ibid.). This is further stressed by Schramn that the essence of communication is getting the receiver and the sender "tuned" together for a particular message. In relation to the purpose of this study that focused on interactions between Daystar University National and International Students, what we can 
realize is that both students play the roles of the source and that of the sender, and do frequently send messages to each other. The basic process of their communication can be equated to one of the communication models Schramm designed (Severin \& Tankard, 1997, 58). This model of communication is represented as follows:

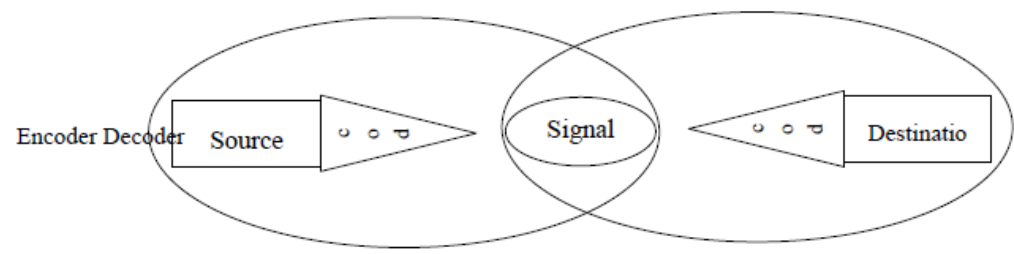

Adapted from Schramm (in Devito 1979, 11)

Figure 3. Schramm's model of communication

From this model, the researcher built the theoretical framework below, which indicates elements of intercultural communication that could help understand the concept of social interactions, and its potential implications:

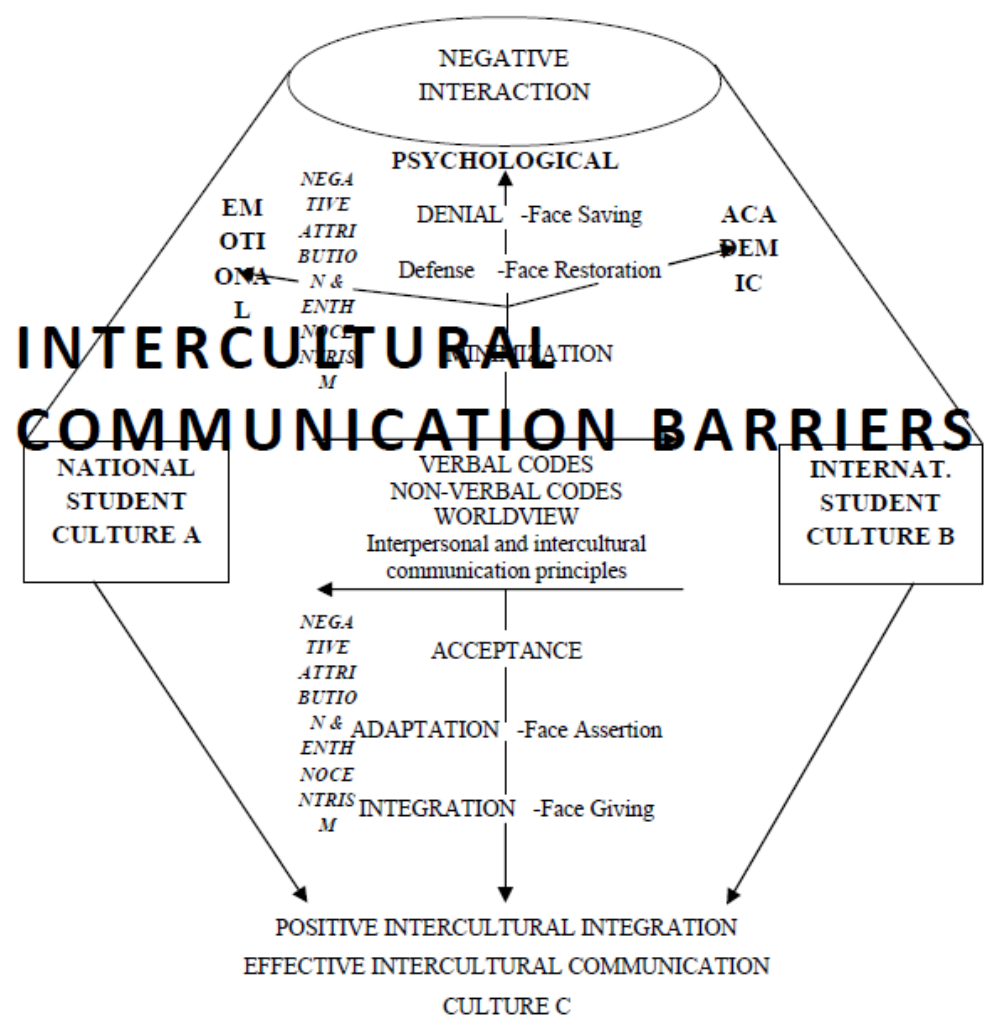

Figure 4. Intercultural Communication Model for Daystar University

\section{Conclusion}

Having listed some of the barriers frequently encountered in intercultural interactions, important principles that need to be followed for the sake of creating understanding between people from different cultures and who are engaged in interactions of any sort, are well understood. It is then up to each person because their culture influences the manner in which the message is encoded and sent or decoded and received. Building on Schramm communication model, a new intercultural communication model that could help understand dynamics of intercultural communication in Daystar University was suggested. These dynamics of intercultural communication were studied through a critical analysis of the 
Texila International Journal of Academic Research

Volume 3, Issue 2, Dec 2016

characteristics of human interactions as they occur between Daystar University National and International Students.

\section{Methodology}

\section{Introduction}

This chapter described the research methods, the data required, the population studied, the sampling technique, data collection tools, data processing, and data analysis procedures used.

The nature of the research was qualitative and for the sake of triangulation, which is a comparability procedure designed to reconcile methodologies (Leedy, 1993, 145), the researcher used two methods.

\section{Methods used}

The following methods were used: Focus Group Discussions and In-depth Interviews to collect data from student's representatives, staff members, and lecturers of communication and culture courses as well as student's representatives. These methods were preferred as they provide "greater depth of response and therefore, greater understanding" as well as a "direct link with the public" (Maleche 1997, 57). Validity and reliability of Focus Group Discussions which measure consistency, stability, or repeatability (Rubin, Rubin \& Piel, 1990, 188) was suitable for focus group inquiry (Kivy 1998, 53). To guarantee reliability, the researcher in this study had two similar groups per categories of students targeted by the study. Also, Focus Group Discussions were led by a moderator who was well-trained and experienced in interviewing techniques (Tull \& Hawkins $(1987,312)$. Discussions were compared to enable the researcher gain new insights into the subject discussed (Beri, 1989, 213). The participants in this study were Daystar University National and International Students, who had been in the university for at least one year.

Focus Groups were small enough to be able to share insights, and yet, large enough to provide diversity of viewpoints (Krueger 1978, 27). They were composed of six to ten people as it had been suggested by Patton and Giffin $(198,335)$. The data required was collected through guidance from the questions that included how both Daystar University National and International Students viewed each other while interacting, verbal and non-verbal communication patterns, conflict management, and policy making and the orientation training programme in Daystar University and their impact on the quality of interaction between the two categories of students. The population studied included the undergraduate students in Athi-River Campus and students in Nairobi Campus. In both groups, first years were excluded probably because they were still at the fascination or tourist stage, which occurs when a person first enters a new culture (Grunlan \& Marvi, 1988, 23). Those in pre-entry level, short courses, and evening students were not also included in the study. Although, their opinions were collected in one of the interviews that was conducted in order to compare their insights for the sake of having a comprehensive view of interactions between students in Daystar University. Sampling was done to reduce costs and save time (Rubin, Rubin \& Piel, 1990, 179). A criteria was followed during sample: a student had to be fully and regularly registered, and had to have studied for at least one academic year, as well as interacting with international students. Focus Group Discussions took place in the afternoon from 5:30 to 7:00 pm and from 9:30 pm to 12:00 pm.

In-depth interviews were also conducted, as a second method to complement data gathered from the Focus Group Discussions. Those who were interviewed included lecturers, administrators, resident tutors, and students' representatives. Sommer and Sommer (1997) stated that an interview gives people the opportunity to tell their stories in their own words. There is also the ability of the interviewer to clarify questions that the respondent does not understand at first hand (Singleton, Straits \& Straits 1993, 261). Open-ended questions were asked by the researcher, which allowed the interviewee to think and speak (Jain, 1998). He also helped the interviewees remain focused on the object of discussion (Brooks 1996, 117). 
The researcher used semi-structured interviews to get opinions from representatives and these were conveniently selected.

Pretesting of Focus Group and interview questions was done before the actual field research. This was done to confirm the validity and reliability of data collection tools. Data collection tools used in this study were: Focus Group Discussions and In-depth Interviews. The moderator's guide was designed to direct discussions toward the purpose and the objectives of the study as suggested by Aubel $(1994,42)$. Data was recorded and managed through note-taking and tape-recording (Aubel 1994, 37). Data processing and analysis as suggested by Stempel III, Westley $(1989,109)$ was done through transcribing of recorded contents. After that, he organized, coded, and analyzed elements of discussions and in-depth interview sessions. Data were analyzed according to the categories of responses found in data itself through inductive process.

\section{Conclusion}

In conclusion, the approach of the study was confined to dynamics, which characterize intercultural communication encounters. Data collected was categorized, coded, and analyzed; the information was then interpreted according to the research problem, purpose, and objectives.

\section{Findings of the study}

\section{Introduction}

In this chapter, the researcher presented the research findings and provided an explanation of these findings whenever appropriate. The findings of the study were presented as they occurred in Focus Group Discussions and In-depth Interview sessions. Hence, they reflect as much as possible the opinions and experiences of participants that were given in response to questions that were asked by the researcher. The approach of presentation was analytical and synthetic in nature confined to the characteristics of intercultural interactions of students in Daystar University.

\section{Research findings}

The research findings were analyzed, organized, and presented in terms of responses in the manner of: common response, difference in response, unique response if any, verbatim questions, comments and explanation by the researcher. A complete list of abbreviations is given in the preliminary pages to facilitate the reading. And also, for the sake of clarity, Focus Group Discussions \#1, \#2, \#5, \#6 represented National Students while participants in FGD \#3, \#4, \#7 were Daystar University International Students. Those who were interviewed were lecturers, administrators, resident tutors, and students' representatives. The findings were highlighted per question in the Focus Group Moderator's guide and in-depth interview questions. If the response was given by all FGD or all interviewees, the researcher used the concept [ALL] to represent their opinions. The abbreviations FGD represented focus group discussions and INT represented an interview session.

Interactions between DUNS/DUIS were not good. They were based on stereotypes and preconceived ideas accumulated more responses, while interactions were good had a few responses, and then, interactions are neutral had the fewest responses, especially participants in INT \#2. Daystar University national students indicated that the international students had a tendency of clustering according to where they come from. While, Daystar University international students indicated that the national students were individualistic. They looked Westernized and seemed not to care about international students. Several participants in FGD \#5 asserted that most of the international students came to Kenya with preconceived ideas and or stereotypes and the convictions that they have from this attitude does not allow them to interact with national students.

Several participants in FGD \#1, \#2, \#3, \#5, \#8, and INT \#1, \#3, \#5, \#7, \#8, \#13 indicated that it was very difficult to have close contacts with international students because closeness 
Texila International Journal of Academic Research

Volume 3, Issue 2, Dec 2016

depended on whether students come from the same country or speak the same language. One of the respondents in FGD \#5 said:

National students tend not to talk to the international students at first because they are not sure of how they are going to react. It is easier for one to talk to a person who comes from one's own country, and this makes the international students feel left out.

On the other hand, participants in FGD \#1, \#5, \#7 told the researcher that international students are careful and thus, they talk slowly and some have difficulty in speaking. In relation to this, one participant in FGD \#5 said that "the problem of not having close contacts is not exclusive to international students studying in Kenya. It is a problem of any human being when in a new environment.” Participants in FGD \#3, INT \#2, and \#14 admitted that most students from up-country were more polite and respectful. They behaved in a manner that is socially accepted for most African contexts.

Several participants indicated that closeness is based on interest and shallow. And thus, there is little or no trust between national and international students. Hence, genuine friendship is somehow impossible.

All most all participants asserted that friendships were good but not as deep as they should be. FGD \#3 and \#4 posited that it is hard to believe in good friendship. One of the participants in FGD \#4 said:

Imagine I have had friends from day one but I do not understand them. I have been here for about four years and I am soon graduating and until now none of them has ever invited me at his home. I am now wondering whether they are my friends or not.

Despite this, some have been invited, just as one of the participants in FGD \#5 declared:

"I have invited one international student and travelled with him to Turkana, he had a good view of Turkana. And had a good swimming in Lake Turkana."

The participants in FGD \#2, \#3, \#4, \#7, and INT \#3, \#4, \#5, \#11, and \#14 indicated that they normally wanted to invite the international students and or national student to their homes or for an outing, but it does not happen because of their busy schedules. Money was also a factor as far as invites were concerned as expressed by participants in FGD \#7. Another in INT \#3 explained why international students were not showing up, even when they got invited or not inviting:

The real problem is that international students join Daystar University after they have received some bad information about Kenyans. Then because of this information, they prefer not to invite them. Personally, I think that the international students are fed with wrong information then they end up by having wrong perception of the national students. This obviously creates some interactional gaps between the two categories of students. In relation to this, my opinion is that they really need to be given a chance of showing who they really are.

Busy schedules dominated responses obtained and that students did not care so much about their colleagues. In INT \#6, a participant revealed that some students are misled on their arrival in Daystar University:

You know my brother, when I first joined Daystar University, most of the colleagues told me: welcome here at Daystar University. But if you want to succeed in Daystar University, forget about social life!

Participants in FGD \#2, \#4, \#7 indicated that when they meet international students, they feel a difference and thus prefer to keep a distance. The attitude of students at this point revealed that they do not apply the principles of interpersonal and intercultural communication in their interactions as indicated in review of literature. Also, participants in FGD \#1, \#2, \#3, \#6, and INT \#3, \#4, \#5, \#6, \#7, \#13 indicated that interactions between Daystar University national and international students were not good. In the other FGD and INT, the participants had a positive feeling about interactions, though some said interactions were still on a superficial level. And thus, something needed to be done for the sake of improvement. 
Some of the participants said that they decided not to generalize over issues concerning the international students and suggested that it is good for people to understand existing cultural differences between national and international students. Though, participants were also certain that students did not understand each other the way they should because of language, as the core challenge. One participant in FGD \#7 asserted that:

The way French speaking people and those from West Africa pronounce English words is wrong and misleading at the point that you hardly get the point when exchanging views and opinions about certain real life issues.

Difficulties were experienced differently by both national and international students. One was respect of personal space. In line with this, one participant in FGD \#2 asserted that:

There are problems related to kinesics and proxemics. International students do not respect personal spaces. Some of them are too touchy and kiss each other openly may they be men or women. Some international students' greetings take long. Such an act gives bad impression and leaves national students wondering what is happening.

On the other hand, a participant from FGD \#3 counteracted that:

National students are too reserved and you do not know exactly what the person is thinking about you. It is hard even to self-disclose. There are times, I want to share a feeling but I do not share it because I fear how the other person will take it. So there is no room for disclosure even if you are experiencing a tough situation that requires encouragement from other. People just look at you.

Another interesting comment was about spitting anyhow. One participant in FGD \#2 said that "some international students spit a lot on the ground and this offends national students. Such an act is backward."

On clustering, one participant in FGD \#2 claimed that:

African international students have a tendency of grouping together. They are always together may be because of past similar and bitter experiences such as the genocide in Rwanda, the war in Democratic Republic of Congo and or Sudan... Others stick together because of cultural similarities such as people from the Horn of Africa, the Great Lakes Region, South Africa, and West Africa. The problem is that if this clustering persists, Daystar University is going to lose its image. In fact, I fear for the future of interactions in Daystar University.

Most FGD and INT participants indicated that students were aware of these difficulties, though they lacked the effort to overcome existing difficulties in order to smooth interactions. They also expressed a concern that the state of interactions had to be reviewed and improved in a way that will help students avoid the noted difficulties. They however testified in FGD $\# 1$, \#2, \#3, \#4, \#5, \#6, \#7 and INT \#2, \#3, \#4, \#5,\#6, \#7, \#8, \#9,\#10, \#11, \#12 that both national and international students made efforts to listen to each other. While several participants in FGD \#4, \#8 and INT \#12 and \#13 alleged that it really depended on the individuals.

On dressing, most participants applauded international students for being original and impressive. One participant mentioned that:

I like the international students because they dress decently. Their ways of dressing, for both men and women, is traditional and therefore respectful.

Although, most participants were of a view that for both categories of students, old ones generally dressed more decently than the young ones. And that the young ladies' dressing was too provocative. One participant alarmed:

When I joined Daystar University and after looking at the way people dressed themselves, I wondered whether Daystar University was a Christian University or not.

On greeting, participants majorly agreed on the same notion that the issue of greeting depends on people's personalities and their cultural backgrounds. They also expressed that in whatever the case, behaviors that students showed were understandable for they all came from different cultural backgrounds and besides, they all had different individual personalities. 
Conflicts occurred once in a while and were generally caused by various issues. Most of the participants attributed this to either cultural differences or basic family social education. One participant argued out that:

Conflicts mainly come from mutually exclusive values, believes and patterns of behavior. The general belief is that national students do not openly say things the way they are, whereas some of the international students say things as they are. This makes some of the national students think that the international students are rude.

In resolving these conflicts, the trend according to the majority of the participants, is that international students tended to withdraw whereas national students were more assertive and aggressive. And also, INT \#1 said that normally, both categories of students did not admit frankly the mistakes they had done. Each one tended to first point fingers to the other.

On the Orientation Training Programme, views and opinions were divided, though there was one point in common. All of them agreed re-visitation of the programme. For instance, most FGD participants noticed that there was a big difference between how American students were oriented and how African students were oriented. Students felt that the programme was discriminatory. One international student in FGD \#6 said:

International students are the same, they all need to undergo the same Orientation Training Programme. The training is discriminative maybe because you are black, those in charge assume that African international students cannot experience difficulties in Africa.

Another participant in FGD \#3 testified:

When I came, I had to spend my first night on a street. I did not know exactly where to go and how to reach Daystar University. I spent my first night outside like a "Chokora." But for the consortium students, everything is set prior from their arrival.

While, the older people expressed that the activities organized for this event were not helpful because nothing was learnt from them. Despite the fact that most people had negative opinions about how the orientation was done, several students were satisfied. Participants believed that the programme needed a thorough review because it mainly focused on fun.

\section{Limitations of the research}

The first limitation had to do with the updated list of students, which was not provided at the time the study was conducted. Therefore, the researcher had to switch to a convenient sampling technique. Timing of meetings was a second limitation due to the students' busy schedules. But the researcher had to plan conveniently. Focused Group Discussions also had to be increased from six to eight in order to sample diploma and masters students separately. Some FGD went as far as late at night and therefore, most of the students were tired. Last but not least, the students were a bit reluctant to participate in the beginning of the study. Some even denied their demographic details with a thought that the researcher was spying for the administration of the university. The researcher had to clarify that the research study was meant for academic purposes and primarily to investigate intercultural communication interactions in the university. This enabled students to feel free to participate in discussions and interview sessions.

\section{Description of characteristics}

\section{National students}

\section{Positive characteristics}

National students have a strong sense of nationalism, accommodating, welcoming, positively proud and hence, more assertive; they are dynamic, and are flexible and quick to adapt.

\section{Negative characteristics}

National students have stereotypes, generalizations, and assumed similarities about international students depending on where these international students come from. They seem 
to be individualistic and self-centered, mix languages when they are speaking together or with international students; they also tend to be explosive and impatient, quick to correct and lazy to read about other countries. National students are Western-oriented and do not care about others, they talk too fast and sometimes ignore the weaknesses of international students.

\section{International students}

\section{Positive characteristics}

International students have a strong sense of nationality and their dressing styles are impressive. They have the best dishes as indicated by participants in FGD \#2, and are more sensitive about what happens in Kenya than national students; they are positively curious. International students do not mix languages when talking to national students, they are time conscious, and respectful to the older people and especially lecturers and ladies.

\section{Negative}

National students have stereotypes, generalizations, and assumed similarities about national students; they are not assertive, and resign earlier in case misunderstanding has occurred, always when involved in an argument, and like to cluster according to where they come from. Most of them do not take part in the activities organized by Daystar University for social welfare, they seem to be study oriented, and lack curiosity about what is going on in the university. Exchange of information with international students is boring most of the time because their messages either relate to war and bitterness, or shallow and not interesting because they do not master English, Kiswahili and or 'Sheng', the three languages that national students fluently speak. Moreover, they communicate slowly and do not follow the rules of English language except for the American students who speak too quickly.

All the above characteristics were discussed in relation to the levels of intercultural communication dynamics. Some characteristics are related to perception, verbal communication, and other to non-verbal communication.

\section{Characteristics of human interactions in relation to perception}

Perception is a complex process that involves psychological influences from the perceiving organism. Perceiver's needs, wants, moods, attitudes, and assumptions form these influences (Severin \& Tankard, 1997, 88). The researcher had a great interest in the dimension of selective perception, which often leads to selective attention (Ibid.). Different characteristics that both categories of students exhibit in their interactions are reflectors of not only their attitudes, beliefs, but also reflection of individual personalities; these influence how students perceive others. That explains why national students perceived international students as people who like to cluster together according to their countries of origin and or regions; French speaking countries including Burundi, Cameroon, DRC, Rwanda, while Ethiopians and Eritreans are always in clusters, then those from other parts of Africa such as West Africa and South Africa. On the other hand, international students seemed individualistic and selfcentered.

\section{Characteristics of human interactions in relation to verbal communication}

From the findings, the two categories of students had two sets of characteristics that place them on two extremes. National students were seen as too talkative and fast, speak freely, were aggressive and assertive; they do not give up in discussion and instead push until they are heard. They also mixed languages while interacting. Yet, international students were quiet and speak slowly. The findings also revealed that interactions between Daystar University National and International Students are characterized by language problems, especially international students. Hence, forcing some international students to use a lot of non-verbal cues. 
Texila International Journal of Academic Research

Volume 3, Issue 2, Dec 2016

\section{Characteristics of human interactions related to non-verbal communication}

Although the study did not address all existing non-verbal communication cues, kinesics, chronemics, and proxemics were examined. On kinesics, it was found in FGD \#1, \#2, \#4, \#5 that gestures or hand and arm movements that fall into different categories (Dodd, 1991, 202) were used by international students more while explaining something in order to support what they are verbally saying. The international students were on the other side concerned with the facial expressions of national students. Eye contact among the young people portrayed them as being not polite because they looked straight in the eyes of the old people when interacting. Greetings also were found to vary with culture. For instance, French speaking peck cheeks regardless of sex and with Sudanese, they were too touchy. Dressing on the other hand was found to be inappropriate, especially for young ladies. It was also too provocative and tended to lead people towards questioning the Christian aspect of the university.

On chronemics, participants indicated that time usage had no significant difference between African international students and national students. However, they acknowledged that American, European, and Asian students were more time oriented.

In relation to proxemics, use of space was generally good but problems occurred in public places like latrines, dining halls, classrooms, and public courts. Participants noted the proper use of space concerned both national and international students. And the analysis of the various responses, it was concluded that interactions between the two categories of students were not as healthy as they should have been.

\section{Factors related to individual characteristics exhibited by students}

The findings of the study indicated that age, sex, money, environment are key factors that affect the quality of interactions between Daystar University National and International students. Even more, peer pressure also impacted negatively.

\section{Techniques used by students when misunderstanding occurs}

From the findings, international students tended to withdraw when misunderstanding occurred whereas, national students pushed on until they were heard, especially among ladies. Participants expressed that a sense of openness between a few Daystar University National and International students and willingness to learn from other generally caused success in interactions. Yet, individualistic attitudes and the grouping of international students according to their origin was pointed out as the major cause of unhealthy interactions between Daystar University National and International Students.

\section{Adequacy of the orientation training programme}

Interactionists and intercultural communication experts like Samovar and Porter, Dodd among others indicate that initial interactions are crucial for effective intercultural communication. Some of the weaknesses of the orientation programme that both the Daystar University National and International Students pointed out included: short and does not consider differences in culture, discriminatory (American students given more attention), one even said,

Before I can tell you something, could you please first define international students because I think international students are a consortium or American students?

Besides, the content of the programme was mainly fun oriented and led by young people, leaving the older students out and does not include the administration.

\section{Recommendations}

\section{To National Students}

Pay attention to the negative characteristics pointed out in the study; individualistic, assertive, and aggressive. Speaking too fast is another characteristic, minimize use of 'Sheng,' or teach 'Sheng' words to the international students. Avoid perceiving international students in terms of pre-existing stereotypes, generalizations, and assumed similarities between some 
individuals of a particular ethnic group, nationality, race. It was good to be an ethno-relativist in the process in order to avoid bias.

\section{To international students}

They should try to be assertive and avoid clustering and also, get much more involved in the university activities. They should also understand life through cultural lenses of national students not accepting pre-conceived ideas, stereotypes, generalizations and assumed similarities about national students, thus reducing the existing cultural distance between them. They should also improve on their frequency on reading noticeboards in order to be updated on all the campus events and activities. The study also recommended a general reading habit, which opens the gate to knowledge and also, discussion of certain cultural values, beliefs, and patterns of behavior.

\section{To both categories of students}

They should understand that people are different and will always be different. Hence, the study recommends that they all go an extra mile to learn from one another. In case of conflicts, Ting-Toomey (Griffin, 1997, 425) said that there are five ways of managing conflict: avoiding, obliging, compromising, dominating, and integrating. There is also need for mediator behaviors of listening, encouraging, and taking the disputant, statements seriously are ways of building positive face.

\section{For the orientation training programme}

The study suggested the Orientation Programme is to be reviewed in both content and processes of execution. Content should consider age, sex, as well as environmental factors, and extension of time to a period of two weeks and include public lectures, conferences, on intercultural communication two to three times per semester. The administration should also get closer and help in restructuring the programme and reduce the distance from students by meeting at least every three weeks, if possible. Moreover, all students should be given the same amount of attention during orientation.

\section{To daystar university}

Servant leadership should start from Daystar University before extending to the rest of the society and that the university promotes intercultural communication principles in all activities and establish a forum for intercultural communication. Also, usher into more unity than difference between the various groups represented in the university. The student development office should also define some basic dressing standards and initiation of intercultural video programmes for sensitization.

\section{For further study}

The researcher recommended for further study a study of student interactions that will evaluate trends after a period of time and establish the correlation between interactions and class drop-outs, poor academic performance and the quality of interactions between students at Daystar University.

\section{General conclusion}

The study was concerned about human interactions between National and International Students at Daystar University. After using Focus Group Discussions and In-depth Interview sessions, the researcher found that human interactions between students were not as healthy as they should have been. Daystar University's philosophy of training servant leaders will be possible if it helps students interact in an atmosphere of mutual acceptance, encouragement, and love that Christianity preaches. The researcher also suggested that University implements all the recommendations as soon as possible. 
Texila International Journal of Academic Research

Volume 3, Issue 2, Dec 2016

\section{Bibliography}

[1]. Adler, R. B. (1995). Interplay: The Process of Interpersonal Communication. $6^{\text {th }}$ Ed. Fort Worth: Harcourt Brace College Publishers.

[2]. Althen, G. (1983). The Handbook of Foreign Student Advising. Chicago: Intercultural Press.

[3]. Anderson, J. A. (1987). Communication Research: Issues and Methods. New York: McGraw-Hill Publishing Company.

[4]. Aubel, J. (1994). Guidelines for Group Studies Using the Group Interview Technique. Geneva, ILO.

[5]. Baker, M. J. (1998). Macmillan Dictionary of Marketing and Advertising. $3^{\text {rd }}$ Ed. London: Macmillan Press Ltd.

[6]. Banks, P. S. (1995). Multicultural Public Relations: a Social-Interpretive Approach. USA.

[7]. Baran, S. J. (1999). Introduction to Mass Communication. California: Mayfield Publishing Company

[8]. Beri, G. C. (1989). Marketing Research. New Delhi: Tata McGraw-Hill Publishing Company Ltd.

[9]. Bormann, E. G. (1980). Communication Theory. USA: Holt, Rinehart and Winston

[10]. Brooks et al. (1996). News Reporting and Writing. $5^{\text {th }}$ ed. New York: St. Martin Press.

[11]. Chalfant, H. P \&Labeff, E. (1988). Understanding People and Social Life: Introduction to Sociology. USA: West Publishing Company.

[12]. Civikly, J. M. (1981). Contexts of Communication. New York: Holt, Rinehart, Winston.

[13]. Coker, D. A \& Burgoon, J. K. (1987) "The Nature of Conversational Involvement and Nonverbal Encoding Patterns" in Human Communication Research. Vol No.4. Texas: Sage Publications, Summer. [14]. Cook, D. A. (1971). Interpersonal Perception. Great Britain.

[15]. Devito, J. A. (1976). Communication: Concepts and Processes. New Jersey: Prentice Hall.

[16]. . (1972) The Interpersonal Book. $6^{\text {th }}$ ed. New York: Harper Collins Publishing.

[17]. Dodd, H. C. (1992). Dynamics of Intercultural Communication. $3^{\text {rd }}$ ed. USA: Brown Publishers.

[18]. Dupraw, M. E. \& M. Axner. "Toward a More Perfect Union in an Age of Diversity: Working on

Common Cross-Cultural Communication Challenges.” [On-line] URL: http://www.pbs.org/ampu/crosscult.html, 2000.12.07.

[19]. Ehrenhaus, P. (1988) "Culture and the Attribution Process: Barriers to Effective Communication" in Theories in Intercultural Communication. Edited by Young Y. Kim and William, B. Gudykunst. California: Sage Publications.

[20]. Fiber, L. L. \& Smith, C. E. (1987). Toward Internationalism: Readings in Cross-Culture Communication. $2^{\text {nd }}$ ed. USA: Newbury House Publishers.

[21]. Gathu, F. W. (1995) Television and the Shaping of Culture in Kenya: a Case Study of Nairobi High School Youth's Use of Foreign TV Programming. Unpublished Doctorate Thesis, Graduate College of Bowling Green State University, USA: Ohio.

[22]. Goffman, E. (1967). Intercultural Ritual. USA: First Pantheon Books Edition.

[23]. Griffin, E. M. (1997). A first Look at Communication Theory. $3^{\text {rd }}$ ed. New York: The McGrawHill Companies, Inc.

[24]. Grunlan, S. A. \& Marvin, K.M. Cultural Anthropology: a Christian Perspective. $2^{\text {nd }}$ ed. Michigan: Zondervan Publishing House.

[25]. Gudykunst, W. B. \& Grumbs, L. I. (1983). “Social Cognition and Intergroup Communication” in Handbook of International and Intercultural Communication. California: Sage Publication.

[26]. Gutek, G. L. (1991). Cultural Foundations of Education: Bibliographical Introduction. USA: Macmillan Publishing Company.

[27]. Holmes, A. F. (1991). Shaping Character: Moral Education in the Christian College. Michigan: Eerdmans Publishing Co.

[28]. Idoc Internationale (1999). The Right to Communicate: a Duty to Particpate (99/1-2). Rome.

[29]. Inch, M. A. (1982). Doing Theology across Cultures. Michigan: Baker Book House.

[30]. Infant, D. A., Rancer, A.S. \& Womack, D.F (1993) Building Communication Theory. $2^{\text {nd }}$ ed. Illinois: Waveland Press, Inc.

[31]. Jain, G. L. (1998) Research Methodology: Methods, Tools and Techniques. New Delhi: Mangal Deep Publications. 
[32]. Johnson, W. D. \&. Johnson, P. F. (1982). Joining Together: Group Theory and Group Skills. $2^{\text {nd }}$ ed. USA: Prentice-Hall, Inc.

[33]. Kivy, B. (1998). The Relationship between Public Commitment and Self-persuasion: a Case of Daystar University's Code of Conduct. Unpublished Master's Thesis, Daystar University, Nairobi, Kenya.

[34]. Kohls, L. R. (1994). Developing Intercultural Awareness: a Cross-Cultural Training Handbook. $2^{\text {nd }}$ ed. Yarmoutn: Intercultural Press.

[35]. Kolstoe, R. H. (1973). Introduction to Statistics for the Behavioral Sciences. Illinois: The Dorsey Press.

[36]. Krueger, R. A. (1988) Focus Groups: a Practical Guide for Applied Research. Newbury Park: Sage Publications, Inc.

[37]. Leedy, P. (1993). Practical Research: Planning and Design. $5^{\text {th }}$ ed. USA: Prentice-Hall.

[38]. Leemon, T. A. (1972). The Rites of Passage in a Student Culture: Anthropology and Education. USA: Teachers College Press.

[39]. Lenfers, A. D. (1997). "How to Evangelize Cultures and Enculturate Faith in Ethiopia Today" in Faith and Cultures in Ethiopia. (Towards a Pastoral Approach to Culture: a Symposium). Addis Ababa: Ethiopia Review of Cultures.

[40]. Levine, R. A. \& Campbell, D. T. (1972). Ethnocentrism: Theories of Conflict, Ethnic Attitudes and Group Behavior. USA: John Willey \& Sons Inc.

[41]. Loewen, A. J. (1975). Culture and Human Values: Christian Intervention an Anthropological Perspective. California: William Carey Library.

[42]. Maleche, N. M. H. (1997). Interpersonal Communication in Counseling Departments in Nairobi. Unpublished Master's Thesis, Daystar University, Nairobi, Kenya.

[43]. Mbennah, E. D. (1994). An Investigation of Source Credibility Factors Among a Select African Audience using Semantic Differential Technique. Unpublished Master's Thesis, Daystar University, Nairobi, Kenya.

[44]. McQuail, D. (1994). Mass Communication Theory. $3^{\text {rd }}$ ed. London: Sage Publications.

[45]. Merkoblatt. How do we Perceive or Shape "Foreign" and "Native" Cultural Identities? Research on Processes of Intercultural Dissociation, Mediation and Identity-Shaping [On-line] URL: http://www.volkswagen-uftung.de/english/merkDrat/merkfund.html.2000.12.07

[46]. Miell, D. \& Dallos, R. (1996). Social Interactions and Personal Relationships. Great Britain: Sage Publications Ltd.

[47]. Miller, A. (1992). A Pre-Departure Cross Cultural Orientation Programme for Daystar University Students Going on Exchange to Christian Colleges Consortium. Unpublished Master's Thesis, Daystar University, Nairobi, Kenya.

[48]. Myers, K. M. (1974). Christian Confronts Culture: a Strategy for Cross-Cultural Evangelism. Michigan: Zondervan Publishing House.

[49]. Myers, L. B. (1999) Walking with the Poor: Principles and Practices of Transformational Development. New York: Orbis Books.

[50]. Odetola, O. T. \& Ademola, A. (1985). Sociology: an Introductory African Text. London: MacMillan Publishers Ltd.

[51]. Okigbo, C. (1995). Media and Sustainable Development. Nairobi: African Council for Communication Education.

[52]. Paige, R. M. (1993). Education for the Intercultural Experience. $2^{\text {nd }}$ ed. USA: Intercultural Press, Inc.

[53]. Patton, R. B. \& K. Griffin, K. (1 Interpersonal Communication in Action: Basic text and Readings. ${ }^{\text {rd }}$ ed. N981) New York: Harper \& Row, Pub., Inc.

[54]. Phillipart, M. (1992). The African Church in the Communication Era: a Handbook of Source Texts for Christian Communications in Africa. Nairobi St. Paul Publications, 1992.

[55]. Rubin, R. B., A. M. Rubin \& Piel, L.J. (1990). Communication Research: Strategies and Sources. $2^{\text {nd }}$ ed. Belmont, CA: Wadsworth Publishing Company.

[56]. Samovar, A. L. \& Porter, E.R (1997). Intercultural Communication: a Reader. USA: Wadsworth Publishing Company. 
Texila International Journal of Academic Research

Volume 3, Issue 2, Dec 2016

[57]. . (1988). Intercultural Communication: a Reader. $5^{\text {th }}$ ed. California: Wadsworth Publishing Company.

[58]. Sarbaugh, L. E. (1979). Intercultural Communication. New Jersey: Hayden Book Company.

[59]. Schermerhorn, J. R., Tankard, W. J (1997). Communication Theories: Origins, Methods, and Uses in Mass Media. $4^{\text {th }}$ ed. USA: Longman Publishers.

[60]. Singleton, R. A. Jr., C. B. Straits., \& M. M. Straits, M. M (1993). Approaches to Social Research. $2^{\text {nd }}$ Ed. New York.

[61]. Smith, K. D. (1984). Make Haste Slowly: developing Effective Cross-Cultural Communication. Portland: Institute for International Christian Communication.

[62]. . (1992). Creating Understanding: a Handbook for Christian Communication across Cultural Landscape. Michigan: Zondervan Publishing House.

[63]. Sommer, B. \& Sommer, R. (1997) A Practical Guide to Behavioral Research: Tools and Techniques. $4^{\text {th }}$ Ed. New York: Oxford University Press.

[64]. Stempel, H. Guido. \& H. B. Westley. (1989). Research Methods in Mass Communication. $2^{\text {nd }}$ ed. New Jersey: Prentice-Hall.

[65]. Stewart, J. (1995). Bridges not Walls. $6^{\text {th }}$ ed. New York: McGraw-Hill, Inc.

[66]. Swanson, L. Curriculum Transformation: Intercultural Communication. [On-line] http://www.inform.umd.edu/diversityweb/leadersguide/CT/Course/swanson.html.07/12/2000.

[67]. Tafoya, D. (1983) “The Roots of Conflict: a Theory and Typology," in Intercultural Communication Theory: Current Perspectives. Edited by William B. Gudykunst. California: Sage Publications.

[68]. Trenholm, S. \& Arthur, J (1999). Interpersonal Communication. $3^{\text {rd }}$ ed. Belmont: Wadsworth Publishing Co.

[69]. Verderber, R. F., \& Verderber, K. S. (1992) Inter-Act: Using Interpersonal Communication Skills. California: Wadsworth Publishing Co.

[70]. Wahlstrom, B. J. (1992). Perspectives on Human Communication. Minnesota: Wm. C. Brown Publishers.

[71]. Watzalawick, P. et al. (1967). Pragmatics of Human Communication: a Study of Interactional Patterns, Pathologies, and Paradoxes. New York: Norton.

[72]. Wood, T. J. (1999). Interpersonal Communication: Everyday Encounters. ${ }^{\text {nd }}$ ed. Belmont, CA: Wadsworth Publishing Co. 